\title{
On the Research and Construction of Logistics Informational Platform in Colleges
}

\author{
Ma Kun ${ }^{1,}$, , Deng JianBin ${ }^{2}$ \\ ${ }^{1}$ The logistic group of Northwestern Polytechnical University, XI'AN 710072,China \\ ${ }^{2}$ School of civil engineering and architecture, XIAN university of technology, XI'AN 710072,China \\ amakun2013@yeah.net
}

Keywords: Logistics in colleges, Informational platform, Research of measures

Abstract. At present, logistics informational management construction in colleges of our country is faced with a great many problems in relation to notions, staff quality, informational methods as well as connection between inside and outside. Therefore, in order to further strengthen the building of logistics informational management in colleges, we are required to establish advanced management notions and thorough management rules, strengthen the construction of human resource and place business management in order so that shared rules for information can be well built.

\section{Introduction.}

Logistics informational construction in colleges means that digital technology, Internet technology and modern telecommunication technology are fully combined to widely utilize all information resources so that logistics management and service level and efficiency can be improved in all facets of daily logistics management and service in colleges.

\section{Significance of the construction of logistics informational management in colleges.}

\section{a. Requirement of being adapted to socialized logistics.}

Logistics in colleges takes charge of the great responsibilities for teaching, researching, living for both students and teachers. Logistics in colleges, in order to satisfy the needs of teaching, researching and living, requires to be developed in a highly efficient direction so as to acquire prominent efficiency, benefits and levels. Significantly, information technology offers strong technological support for the improvement of logistics management and service level.

Through informational construction, information and internal logistics management mechanism reform can be combined to boost the transformation of management notions, managing staff quality and managing sections. Managing sections will be flattened and managing activities regulated to better logistics management and service and actively promote management and service to be scientific and humane. Based on the traditional logistics management, a fictive digital space can be built to expand the time and space of logistics management and service, increase the efficiency of traditional logistics management and extend the functions of traditional logistics management.

Only in this can we realize a paperless office as well as transmission networks, resource sharing, activity digitization and scientific decision-making to reach the purpose of increasing logistics management and service level.

\section{b. Requirement of the development of Internet and information technology.}

With the development of Internet technology, Internet has interconnected hundreds of thousands of computers from all over the world and become an indispensable part in our daily life. Informational higher education, as a part of informational education, has connected offices, classrooms, libraries, laboratories, dormitories and canteens with each other.

As Internet is spreading and education systems with quality and inexpensive modern information are widely applied, logistics system as a subsystem higher education will definitely give priority to its informational building to be adapted to fast paces of informational building of the entire world. 


\section{Current situations of logistics informational management building in colleges.}

\section{a.Diverse forms of expression at present.}

Currently, logistics informational building in different colleges of our country shows diverse characteristics and develops in an imbalanced way. For instance, some logistics corporations just bring in technologies like WORD and EXCEL to satisfy some special needs. Some logistics corporations apply One-Card System involving eating in canteens, paying water and electricity fees and swiping cards through gates.

However, it fails to involve other related business and comprehensive management. In addition, some other logistics corporations possess advanced logistics management system which is called “ digital logistics", not only including all the consumption, cost and calculation facets of the former phases., but also being able to comprehensively process and analyze business of the departments that are in the charge of logistics corporation. Therefore, it is a long way ahead to accelerate the paces of logistics informational building in colleges.

\section{b. Problems in the process of building a logistics informational system.}

First of all, people have basically possessed concepts of informational logistics but hold diverse perspectives in regard to informational logistics in colleges. Some think that the application of various management software equals to the realization of automatic management service. As a matter of fact, the above opinion is too subjective.

The virtual requirement of informational logistics in colleges is " completely coordinating resources of the internal and the external, improving management and service level" while “ applying advanced informational technologies like computer, telecommunication and Internet” is a means. Thus, it is necessary to hold sustainable and motive perspectives to treat informational logistics in colleges and constantly update notions with technologies developing and management concepts being upgraded.

Secondly, the overall quality of logistics staff is relatively low. At present, in colleges of our country, cadres in logistics teams are unfamiliar with entrepreneurial management while the overall cultural quality of workers is too low. In addition, problems such as a lack of basic business quality and aging population are also prominent.

Thirdly, professional talents are deficient. Due to the habits which have been developed in the long time, logistics management in colleges is rather casual with something decided against the rules. Therefore, informational logistics will experience a twisted path unless it is based on accurate management principles and regulated business processes.

Last but not least, the connection between internal and external resources is unsatisfactory. The main body of logistics in colleges consists of different organizing forms as well as managing and functional departments with different functions. Its service target is to provide living and teaching service for both teachers and students of the entire college. In terms of the traditional logistics management, decision-making right belongs to the leaders, which results in dispersive work. Under such a circumstance, decision-making is separated with executing and employees' initiative and innovation are completely restricted. Consequently, the logistics management system is not able to timely react to teachers and students with competitiveness lowered..

\section{Measures to logistics informational building in colleges.}

\section{a. Establishing advanced managing concepts and rules.}

Firstly, managing layer is supposed to update managing concept of the logistics corporation, learn modern enterprise managing theories and improve their individual qualities and capabilities. Secondly, a managing system must be created which should be adapted to the modern development, especially the managing rules which match informational construction.

On one hand, we ought to make a computer training plan for all staff as well as its using regulation. On the other hand, the connection between hardware devices and Internet system is supposed to bridged and constructed. Moreover, a information sharing platform should be 
established to improve business efficiency and adapt ourselves to the modern society with information and Internet being considered as the breaking breaches. Only in this way can we create a humanistic and technological context for the forming of logistics culture and sustainable development of a logistics cause.

\section{b. Intensifying the construction of human resource.}

At present, it is obvious that our contemporary logistics team can hardly catch up with the informational development. Informational logistics will definitely develop slowly in such a human resource context.

Thus, colleges are supposed to hire talents who have informational awareness and who are proficient in applying informational technologies to add into the logistics teams. In the mean time, it is essential to cultivate excellent laborers with acute innovation, valid technological base and remarkable skills to develop a prominent producing, serving and managing team.

To realize the employment of advanced employees, we ought to build up and improve computer training and learning regulation, which allows all staff to make full use of the teaching power in the college. Besides, executing and stimulating means are supposed to be used to impulse the management staff to study more. What's more, another good idea is to actively bring in excellent talents to realize specialization in a young age.

\section{c. Regulating business management.}

The standardized building of informational logistics in colleges includes two aspects, electronics with service control and digitization with management control. The foremost task is the overall plan of the entire system after which the information network system centering colleges' management and service system will form a management and service with united rules and data principles.

In addition, only the information guaranteed to flow between different logistics business departments can we fully take the advantage of information system, avoid repeat labor and realize shared information. In the mean time, we are supposed to choose the chief problems to push the development of informational construction according to situations in different phases.

More importantly, the logistics informational construction project can be divided into different stages where we are able to deal with different informational tasks. Through this way can we boost the construction project step by step before all tasks are completed.

\section{d. Transform the traditional notions.}

Informational logistics must regard the supply of convenient, fast and all-around service as its driving power and continuously improve its informational construction according to the requirements put forward by those service objects. To be accustomed to this ever-changing world, traditional notions must be transformed. The traditional way colleges and universities have experienced can never be adapted to this innovative society. Thus, transformation for logistics informational construction in colleges and universities needs to be made.

Only in this way can we create a better system to further promote the development of logistics informational construction in colleges and universities and make a more promising future for the logistics cultivation in colleges of our country.

\section{Summary.}

At present, information construction of logistics management in Chinese colleges are faced with a series problems of thinking concept, personnel quality, information method and interconnection. In order to enforce information construction of logistics in colleges and universities, it is necessary to build up advanced management concept, establish perfect management and information sharing system, strengthen human resource construction and operation control.

Logistics informational building in colleges is a long-time and complicated systematic project and we should fully realize the increasing significance of informational logistics in logistics management in colleges. 
Informational logistics will definitely promote the constant socialized reform of logistics. And as logistics socialized reform in colleges constantly upgrades itself, building a information system which matches the management and service pattern of logistics in colleges is to be the main developing trend.

\section{References}

[1] CuiBaoguo, Theory and Pattern of Informational Society[M], Beijing: Higher Education Publications, 1999.

[2] LiHuaijun, Construction of Informational Management and Management Team in Colleges[J], Academic Paper of Yangzhou University, 2004(3):30-32.

[3] Caixu, Thought of Logistics Informational Building in Colleges[J]. Informational Education, 2006(6): 63-64.

[4] Ronald H. Ballou. Logistics Network Design: Modeling and Informational Considerations[J]. The International Journal of Logistics Management,1995,62:.

[5] Anonymous. Armstrong \&amp; Associates Launches 3PL Advisor Logistics Provider Rating and Informational Website[J]. Wireless News,2011,:.

[6] DengZhijian, On Informational Construction of Logistics in Colleges[J]. Technological Information, 2008(22). 